\title{
Supporting of the Company Strategy Through ERP System
}

\author{
Jozef Kováč, Jaroslava Kádárová* \\ Technical University of Košice / Faculty of Mechanical Engineering / Department of Industrial Engineering and Management, Nëmcovej 32, \\ 04187 Košice, Slovak Republic
}

\section{BIOGRAPHICAL NOTES}

prof. Ing Jozef Kováč, CSc., was born on 1952 in Košice, Slovakia. He is professor in Industrial Engineering from 2001 year. In 1976 he graduated at the Technical University of Košice. After graduation, two years, he worked in practice. Since 1978 he has been operating on Technical University of Košice. From 2009 he is the head of the Department of Industrial Engineering. As a co-worker, she participated on many grant projects VEGA and KEGA. Currently, the co-worker involved in four grant projects VEGA, KEGA and applied research. Prof. Ing. Kováč, CSc, PhD. is co-author of six monographs, 12 university textbooks and other teaching materials, many scientific papers in domestic and international journals, 78 domestic and 53 foreign contributions to conferences.

doc. Ing. Jaroslava Kádárová,PhD., was born on 1975 in Košice, Slovakia. She is associate professor in Industrial Engineering from 2010 year. In 1998 she graduated at the University of Economics in Bratislava. After graduation, she worked in practice as a financial analyst, adviser methodical accounting and business in the area of controlling, plans and statistics. From 1999, she is issued of corporate governance in dealing with the crisis, in a theoretical and practical level. Adviser is to solve business critical events that are primarily related to financial issues. Since 2000 she has been operating on the Department of Management and Economics. In 2007 and 2008, she was the deputy head of the Department for education. As a co-worker, she participated on grant projects VEGA and KEGA. She is co-author of three monographs home, 9 university textbooks and other teaching materials, 46 scientific papers in domestic journals, 28 scientific papers in international journals, 64 domestic and 27 foreign contributions to conferences.

\section{KEY WORDS}

Enterprise Resource Planning - ERP; company strategy; ERP strategy.

\section{ABSTRACT}

Enterprise resource planning (ERP) systems are highly complex business information systems. The implementation of these systems requires a high cost, company time and resources. This article identifies supporting of the company strategy through the ERP system. Successful implementation of the business strategy should be supported by an appropriate ERP system. An empirical and research study of an implementation process of company strategy through ERP system is presented and discussed in terms of the key factors. Our attention is focused on the most critical areas of ERP systems and implementation process of the company strategy the abstract section. 


\section{INTRODUCTION}

Many companies start a selection ERP project by asking the users what they need in a new system. This approach will miss key requirements needed for the business to succeed with its business plan. The business needs to be sure the business strategy is input and linked to the ERP strategy. [6]

A new ERP system is one of the components of the company information technology strategy, and the information technology strategy should support the company's business strategy. The company business strategy should be one of the inputs to the ERP requirements.

\section{Company Strategy}

Most companies have a multiyear business plan. The plan usually includes the following:

- Vision of next few years for the company.

- Mission statement.

- Annual goals and objectives.

- Strategies.

- Plans and action.

- SWOT analysis (Strengths, Weaknesses, Opportunities, Threats).

- Competitive and market analysis.

- Critical success factors that are needed to achieve vision and goals.

- Key measurements.

Often the company management has the enterprise departmental managers develop business plans to support the company plan. When planning the needs of the future system, the company and the department plans need to be input to the definition of the new system. The business plan can drive critical requirements for the new system.

ERP selection team assists the development of a Business Goal Driver Framework. This framework will link critical ERP software requirements to the business goals. The framework has the following linkage:

- Business goals are linked to strategies.

- Strategies are linked to processes.

- Processes are linked critical software function.

The development of this framework depicts how the company business plan is linked to the future ERP system. The ERP team builds a framework that shows the connection of the:

\section{- Goal to Strategy.}

- Strategy to Process.

- Process to ERP Requirement.
By analyzing the business goal, and linking it to a business strategy, that links to a business process, and ERP requirement, the Team has identified and defined a critical requirement that will be used to evaluate ERP software. This framework communicates to everyone involved in the project the importance of the software requirement. It also establishes a clear objective and ROI for management in the implementation of a new ERP system. [2]

\section{Assumptions of the Successful ERP Project}

The ERP project has to be aligned with overall business strategy. This reader is absolutely right: aligning an ERP implementation with a company's overall business strategy is a difficult and often overlooked component of a successful project. I think the main thing needed is to take a top-down approach to defining business processes and then ultimately arriving at an ERP solution that fits the overall business. [7]

In other words, before you can configure a system to enable your desired to-be processes, you need to define what these to-be processes look like. In order to understand your to-be processes, you need to know your operational strategy. And before defining your operational strategy, you need to define your overall corporate strategy and objectives.

So this is why the appropriate approach to ensure a successful ERP project that is aligned with the overall corporate and operational strategy is to:

Define corporate strategy and objectives. Typically, management has to look at a 3-5 year horizon when helping company through the process. They also are challenged to answer the question: "where do you want the company to be in 5 years?" Also, "what operational strategy is required to enable this higher-level corporate strategy?"

Once they have clearly articulated the company strategy, then management need to define its "tobe" business processes that will enable this corporate and operational strategy.

Then, establish the performance measures at the corporate, operational, and business process levels. These measures should help them identify how successful you have been in executing against their defined strategy. They should also align with reports that come out of ERP system.

Finally, they can begin designing, configuring, 
and testing the system to ensure that it is aligned with 1-3.

The unfortunate thing is that most companies start with 4 and skip steps 1-3. By following all four, however, companies can be better prepared to ensure ERP alignment with overall company strategy. Organization's overall business strategy should drive ERP project from start to finish. This is especially true when it comes to defining business processes. [1]

A successful ERP implementation requires a focused and dedicated project team that understands the importance of defining "current state" and "future state" business processes. Organizations that define business processes before software selection are less likely to lose sight of the big picture of benefits realization because they recognize the role that business processes play in achieving corporate goals and objectives. [5]

\section{Benefits of ERP systems}

Although it is possible to define business processes without focusing on corporate strategy, relying on ERP software to automatically meet business needs with out of the box functionality can result in inefficiencies and workarounds. Needless to say, this can impede achievement of measurable business benefits for any organization. Defining current and future state business processes is essential if the company hopes to achieve the business benefits it expects from the alignment of ERP software with overall corporate strategy. Unsettling data from 2013 ERP Report reveals that $60 \%$ of companies achieve $50 \%$ or less of expected business benefits. [3]

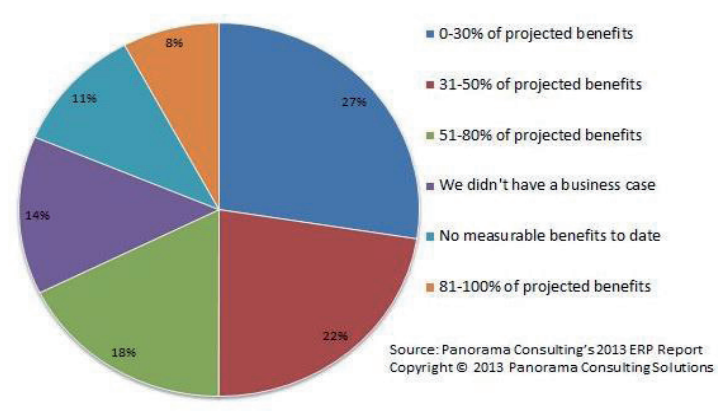

Fig. 1: Percentage of ERP system benefits [4].

The study was conducted by Panorama Consulting Solutions via online polling. Information was collected from September 2012 to January 2013. The 172 participants represent organizations who have worked on ERP initiatives in the past year. [4]

This is a significant drop from last year's findings, which showed that 50-percent of respondents realized greater than 50-percent of their anticipated benefits and only four percent of respondents indicated that they had received no benefits from the project (an additional two-percent didn't have a business case). It is worthwhile to posit that the lower benefits realization may correlate to the lower total cost of ownership seen this year, as organizations looking to shave costs and time typically (and regrettably) nix the business case and other key measurement activities in an effort to get the system installed quickly and cheaply.

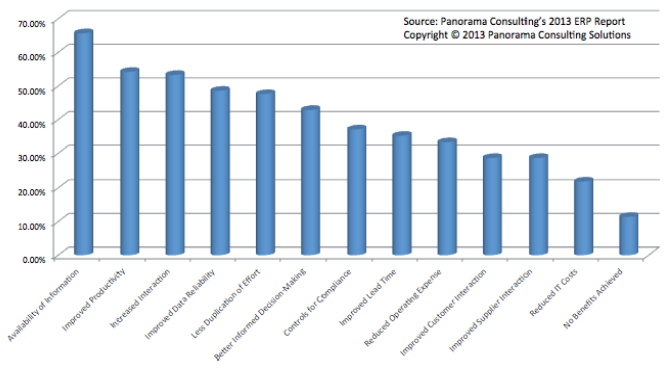

Fig. 2: Benefits types of realized ERP systems [4].

In terms of specific benefits realized by the organizations, responses line up with previous years' findings. As shown above, the top five benefits noted by organizations included availability of information, improved productivity, increased interaction, improved data reliability and less duplication of effort. ERP implementations seemed to have little positive effect on IT costs (which makes sense given the IT department's likely staffing and hardware expenditures), supplier or customer interaction or even operating expenses.[3]

\section{ERP strategy in context of company strategy}

Next sections, is speaks about internally creating the vision and strategy for maximizing ERP investment over the long-term. It all starts with having an ERP application strategy roadmap.

The ERP application strategy roadmap documents the application strategy that enables the stated business goals, strategies, and processes to be achieved given the IT goals, governance, and capacity. Generating and maintaining ERP applica- 
tion strategy roadmaps will ensure alignment between business goals, strategies, and performance targets to the required ERP functionality. In addition, the application strategy roadmap provides the framework for a shared prioritization mechanism for conflicting business and IT priorities. Consider the figure 3 .

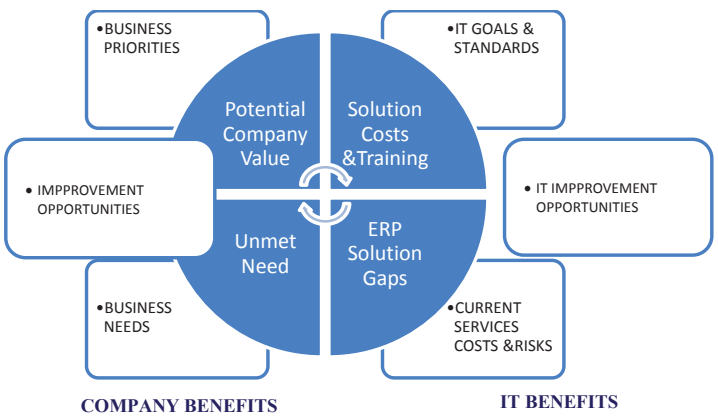

Fig. 3: ERP application strategy roadmap [3].

Practically speaking, there will always be two different perspectives for ERP strategy and prioritization. What is important is that your organization has an ongoing process to align business priorities and IT priorities for your business solution. Having an ERP application strategy roadmap is a deliverable that will support the alignment process. In the next section, we will address the activities for creating an ERP application strategy roadmap.

The following illustration outlines the key activities to perform in creating an ERP application strategy roadmap.

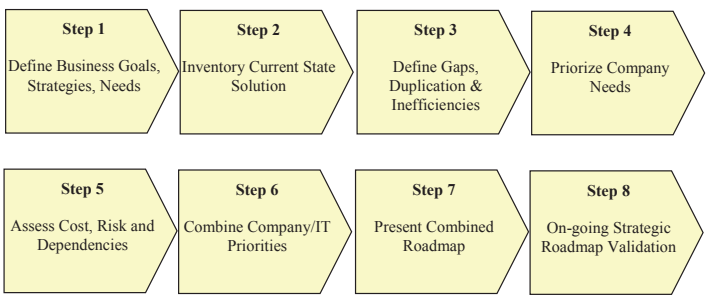

Fig. 4: ERP application strategy processes [3].

For brevity sake, I would like to focus on two key activities that are typically overlooked during the development ERP application strategies:

\section{Step 2 - Inventory Current State Solution Step 3 - Define Gaps, Duplication, \& Inefficiencies}

Once your organization defines the business goals and strategies (Step 1), the next analysis is to determine what components are in place to sup- port the business needs.

In the illustration above you see that the business objectives are supported by a series of business strategies that provides the first level of support for meeting the agreed upon objectives. Business strategies are further elaborated into the individual business processes, people, and ERP capabilities that will support the implementation. Performing this experience is important in order to identify the required interdependencies between the components of a business solution. [3]

Once the above analysis is performed, the next step is to conduct an ERP assessment. The ERP assessment will provide you with the insight needed to understand how your organization utilizes your ERP system. This analysis will enable you identify opportunities to better align with business objectives and goals. In additional to finding opportunities your organization should identify gaps and duplicate functionality that should be addressed. Consider the following figure 5 .

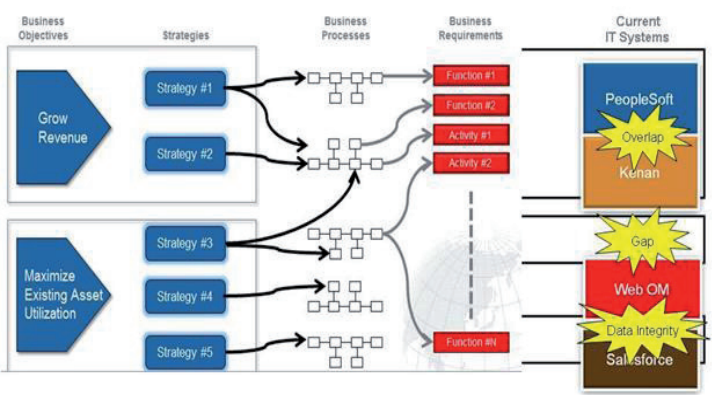

Fig. 5: Identifying ERP system gaps and duplications [3].

An important exercise that needs to be performed is to map business requirements to the existing ERP solution(s). The above illustration is an example of mapping business objectives to the individual systems that would say objectives. This exercise is very useful for identifying gaps and functionality overlap (Step 3).

Performing a current assessment (Step 2) and identifying opportunities and gaps within the current ERP environment (Step 3) is no small feat of effort. Many times these activities are perceived as "looking back" and generate no real value of moving forward. I humbly disagree and say that these activities are vital to enabling customers to move forward with a realistic and achievable strategy. Without an ERP application strategy customers are "blindly following" the ERP vendor's application 
strategy - which may not be in the best interest of a single individual customer.

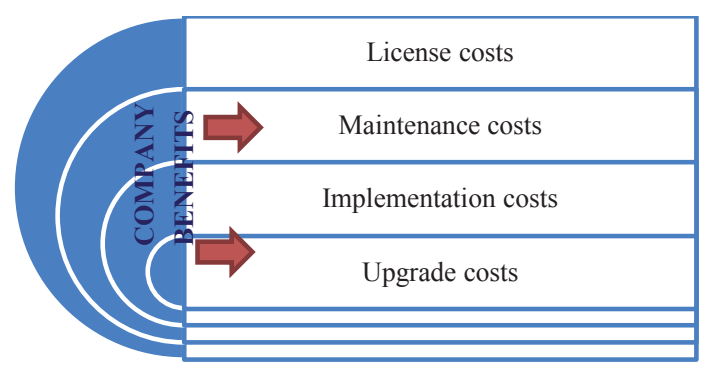

Fig. 6: ERP Return on investment analysis [3].

It is important to realize that your ERP solution will have incremental costs (red arrows) throughout the ERP life-cycle. Without an ERP application strategy in place, your organization is taking a gamble that business benefits from ERP will continue to outpace the corresponding operational costs. Development cost implementation ERP systems is on figure 7.

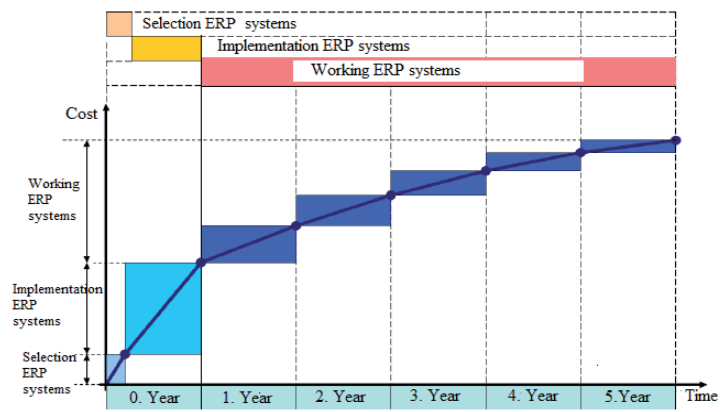

Fig. 7: Development cost implementation ERP systems.

\section{Conclusions}

ERP is a technology strategy that integrates a set of business functions, such as finance, human resources and purchasing, with operational aspects, such as manufacturing or distribution, through tight linkages from operational business transactions to financial records. The right approach to ERP will depend on how business value will be realized. Correctly implemented ERP systems can offer a significant range of benefits in a number of different areas. ERP systems can be used as key enablers of strategic business objectives.

\section{Acknowledgments}

This contribution is the result of the projects implementation: Project VEGA 1/0669/13 Proactive crisis management of industrial enterprises based on the concept of controlling

\section{References}

[1] Aldrich J.: Defining Business Processes to Support Your Overall Business Strategy. 2013, http://panorama-consulting.com/using-business-processes-to-support-your-overall-business-strategy/

[2] Carr J.: Business Strategy - Where Does It Fit With ERP? 2009, http://it.toolbox.com/blogs/business-process-improvement/business-strategy-where-does-it-fit-with-erp-30709

[3] ERP Application Strategy Roadmap for Maximizing Long-Term ROI. 2011, http://gbeaubouef.wordpress. com/2011/07/02/erp-long-term-roi

[4] Kádár, G.: Implementation of innovative methods and techniques for improving competitiveness in selected Slovak companies. Diz. práca,. SjF TU v Košiciach, 2011

[5] Kádárová, J.: ERP systém v priemyselnom podniku. Národní tandemová konference : Zlín, 13.3.2012. - Zlín : Univerzita Tomáše Bati, 2012. - ISBN 978-80-7454-153-7. - P. 80-88

[6] Kádárová, J.: Analýza trhu ERP systémov. In: Transfer inovácií. - ISSN 1337-7094. - Č. 21 (2011), s. 271-274. Spôsob prístupu: http://www.sjf.tuke.sk/transferinovacii/pages/archiv/transfer/21-2011/pdf/271-274.pdf

[7] Panorama Consulting Solutions: 2013 ERP Report. 2013, http://Panorama-Consulting.com/resource-center/2013erp-report/.

[8] Rajnoha, R.: Strategický manažment. Technická univerzita vo Zvolene, Zvolen 2010. ISBN 978-80-228-2204-6.

[9] Teplická, K.: Zisk a jeho efektívne riadenie v podniku. In: Zisk manažment. Roč. 5, č. 1 (2013), s. 46-47. ISSN 1337-9151.

[10] Turisová, R. - Majský J.: Integration of management systems in company. In: Acta Moraviae. Vol. 4, no. 7 (2012), p. 65-68. ISSN 1803-7607. 


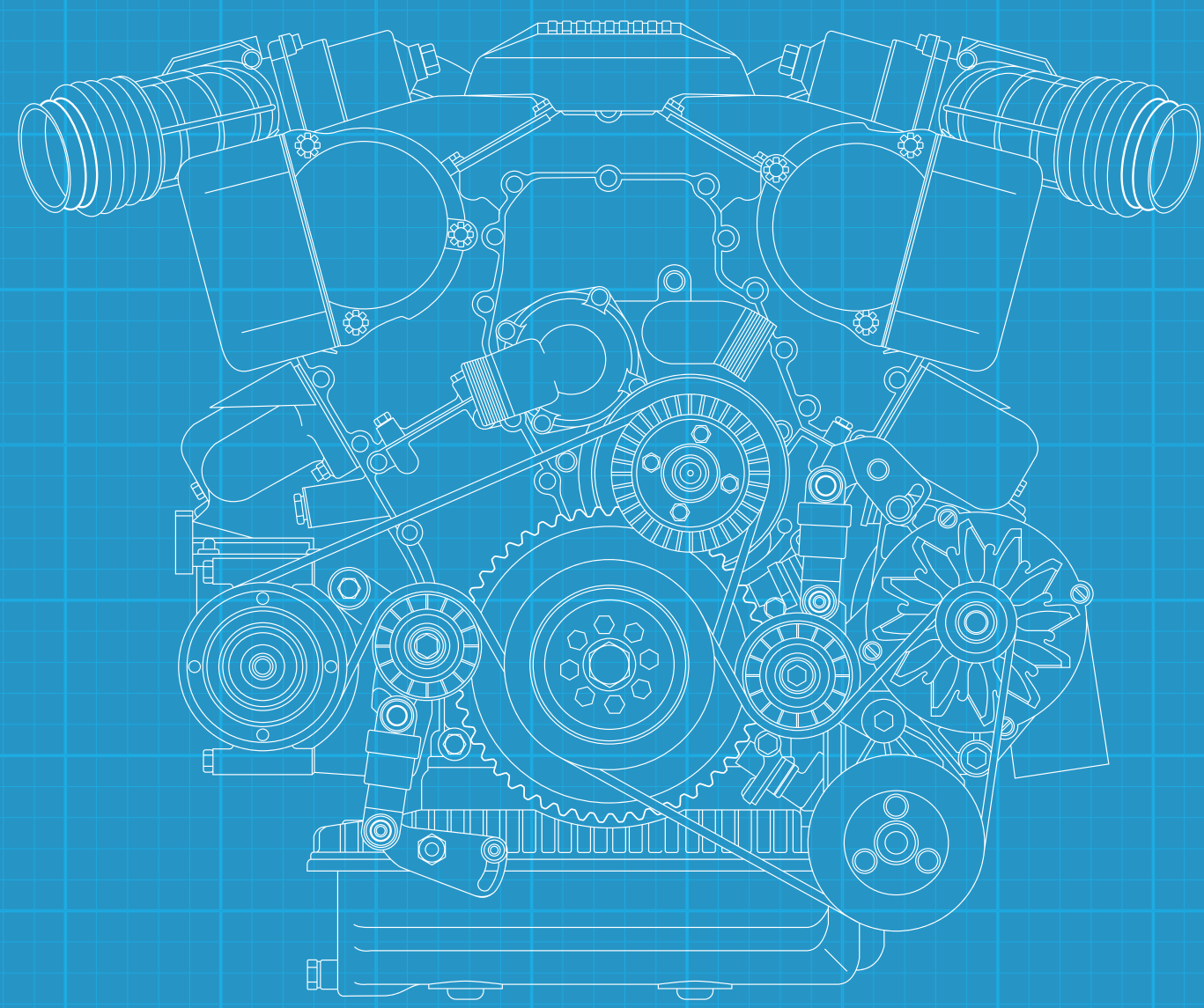

\section{DETAIL}

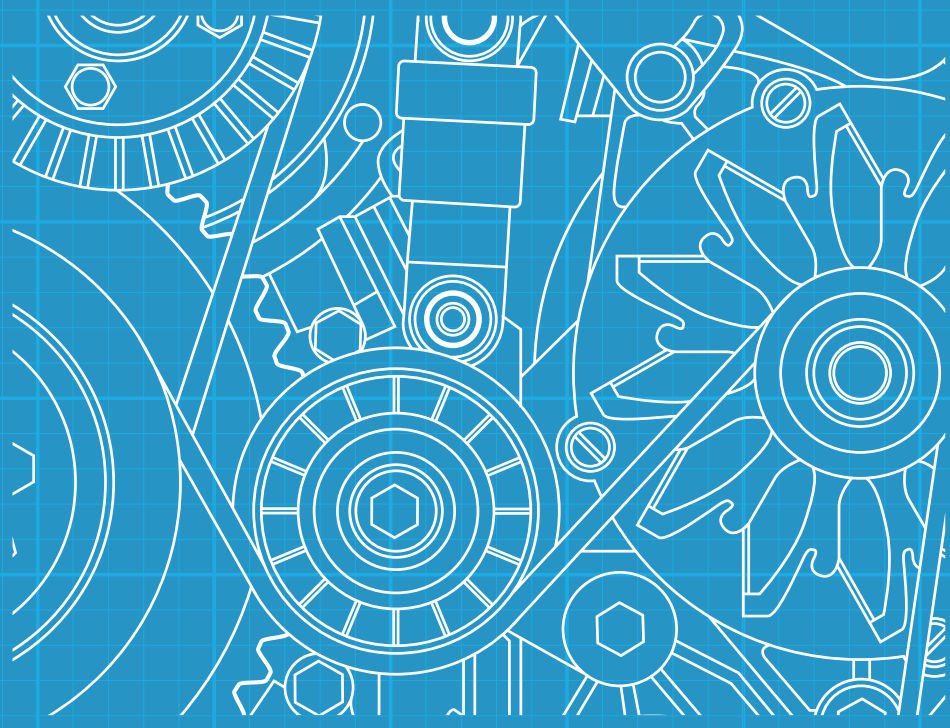

